\title{
The comparison of cardiovascular risk factors prevalence among Catholics and Seventh-day Adventists living in southern Poland
}

\section{Anna Majda', Joanna Zalewska-Puchała', Iwona Bodys-Cupak', Alicja Kamińska ${ }^{1}$, Marcin Suder ${ }^{2}$}

'Institute of Nursing and Midwifery, Faculty of Health Sciences, Jagiellonian University Medical College, Cracow/ Pracownia Teorii i Podstaw Pielęgniarstwa, Instytut Pielęgniarstwa i Położnictwa, Wydział Nauk o Zdrowiu, Uniwersytet Jagielloński Collegium Medicum, Kraków ${ }^{2}$ AGH University of Science and Technology, Faculty of Management, Cracow/ AGH Akademia Górniczo-Hutnicza, Wydział Zarządzania, Kraków

CORRESPONDING AUTHOR/AUTOR DO KORESPONDENCJ:

Anna Majda

Pracownia Teorii i Podstaw Pielęgniarstwa Instytut Pielęgniarstwa i Położnictwa WNoZ Uniwersytet Jagielloński Collegium Medicum ul. Michałowskiego 12, 31-126 Kraków e-mail: majdanna@pczta.onet.pl

STRESZCZENIE

Słowa kluczowe:

ABSTRACT

Key words:

\section{PORÓWNANIE ROZPOWSZECHNIENIA CZYNNIKÓW RYZYKA SERCOWO-NACZYNIOWEGO WŚRÓD KATOLIKÓW IADWENIYSTOWW DNIA SIÓDMECO ZAMIESZKUJACYCH TEREN POLSKI PORUDNIOWEJ}

Wstęp. Przegląd literatury dotyczący przynależności religijnej i chorób sercowo-naczyniowych, nie wykazał jednoznacznych zależności między tymi zmiennymi.

Cel pracy. Określenie wybranych czynników ryzyka sercowo-naczyniowego oraz ryzyka incydentu sercowo-naczyniowego wśród Adwentystów Dnia Siódmego (ADS) oraz Katolików.

Materiał i metody. Badania przekrojowe przeprowadzono w latach 2014-2015, wśród 252 osób, w tym 118 wyznawców Kościoła ADS i 134 Katolików, między 20 a 95 rokiem życia, zamieszkujących teren Polski Południowej. Oparto je na wynikach: pomiarów antropometrycznych, kwestionariusza wywiadu, badania przedmiotowego i badań laboratoryjnych oraz skali SCORE.

Wyniki. Średnie stężenie homocysteiny i triglicerydów wśród Katolików było istotnie wyższe niż u ADS. Adwentyści mieli istotnie wyższe ciśnienie tętnicze oraz średnie stężenie cholesterolu HDL w stosunku do Katolików. Na podstawie BMI u nieco większego odsetka Katolików stwierdzono nadwagę i otyłość, a na podstawie obwodu pasa częstszą otyłość androidalną niż u ADS.

Wnioski. Ryzyko incydentu sercowo-naczyniowego w oparciu o skalę SCORE u Katolików było istotnie wyższe niż wśród ADS. choroby sercowo-naczyniowe, klasyczne i nowe czynniki ryzyka, Katolicy, ADS

\section{THE COMPARISON OF CARDIOVASCULAR RISK FACTORS PREVALENCE AMONG CATHOLICS} AND SEVENTH-DAY ADVENTISIS LIVING IN SOUTHERN POLAND

Introduction. A review literature concerning the religious affiliation and that of cardiovascular disease did not show any clear correlations between these variables.

Aim. To determine selected cardiovascular risk factors and the risk of a cardiovascular event among Seventh-day Adventists (SDA) and Catholics.

Material and Methods. A cross-sectional study was carried out in the years 2014-2015 among 252 people, including 118 Seventhday Adventists and 134 Catholics over 18 years of age, residents of southern Poland. The results of the following were analysed: anthropometric measurements, an interview questionnaire, physical examination and laboratory tests, as well as the SCORE scale. Results. The mean concentration of homocysteine and triglycerides in Catholics was significantly higher than in Adventists. Adventists had significantly higher blood pressure and mean HDL cholesterol concentration than Catholics. On the basis of BMI, overweight and obesity were ascertained in a somewhat greater percentage of Catholics than Adventists, and on the basis of waist circumference, android obesity was found to be more common in Catholics than in Adventists.

Conclusions. Based on the SCORE scale, the risk of a cardiovascular event was significantly higher in Catholics than in Adventists. cardiovascular disease, classical and new risk factors, Catholics, Seventh-day Adventists (SDA) 


\section{INTRODUCTION}

In the Polish scientific literature there are not many publications concerning the results of research on the relationship between religion and human health, and on determining cardiovascular risk factors within religious groups, although interest in this subject is growing among nurses and public health professionals. However, previously published data from many epidemiological studies carried out in the world have suggested a positive link between religion and survival rate and the beneficial impact of religion on reducing the incidence of coronary heart disease, cancer, and mental illness [1-4]. It has been decided to broaden the knowledge about "classical" and "new" cardiovascular risk factors in selected religious groups: Seventh-day Adventists and Catholics, and analyse the relationship between the risk of cardiovascular disease and religious affiliation. The study included both young people (candidates for modern prevention) as well as the elderly (potential patients of multiple departments and beneficiaries of systemic actions using the obtained results to reduce the prevalence of health problems). Research on the frequency of CVD risk factors occurrence in various social/religious groups enables prediction of disease risk and optimization of preventive measures.

The occurrence and mortality due to cardiovascular disease are linked with the occurrence of risk factors for atherosclerosis [5]. These can be divided into conventional modifiable risk factors and new modifiable risk factors, as well as non-modifiable risk factors (e.g. age, gender), which allow to identify individuals at high risk of developing cardiovascular disease. Modifiable factors are linked with lifestyle (diet, smoking, low physical activity) and biochemical and physiological factors (dyslipidaemia, diabetes, hypertension, obesity, metabolic syndrome, prothrombotic factors, homocysteine, and inflammation markers) [5-8].

\section{AIM}

The aim of the study was to assess the prevalence of cardiovascular risk factors among Seventh-day Adventists (SDA) and Catholics (C). In particular, the following selected modifiable cardiovascular risk factors were assessed: the classical ones: dyslipidaemias, arterial blood pressure, blood glucose level, obesity; the new ones: homocysteine, CRP. The study was also designed to show whether religious affiliation affects the risk of cardiovascular death in SDA and Catholics.

\section{METHOD}

\section{Measures}

The present cross-sectional study encompassed anthropometric measurements (body mass and height as well as waist circumference), physical examination (blood pressure), and laboratory tests (CRP, homocysteine, glucose, total cholesterol, HDL and triglycerides) as well as an assessment of the risk of cardiovascular events occurrence on the basis of the SCORE scale [4,9-11]. Furthermore, some selected pieces of information obtained from an authorship interview questionnaire were used (questions on socio-demographic data, smoking cigarettes).

\section{Data and Sample}

The research was carried out in the years 2014-2015 among 252 people. The selection of the studied group was targeted and the sample size dictated by the project's financial resources. The SDA and Catholics were reached through notices/advertisements informing about the study, and the schedule was established by pastors or priests. Subjects were recruited from SDA and Catholics living in southern Poland. The respondents were assured of anonymity, informed of the study's assumptions and its course, voluntary participation, and the opportunity to withdraw from participation at any stage of the study. The criteria for inclusion in the study were over 18 years of age and practising the SDA or Catholic religion. Exclusion criteria were the following: not practising the given religion, pregnancy, breastfeeding, autoimmune diseases, cancer, and operations within the last 3 weeks.

\section{Ethical considerations}

The study protocol was approved by the Jagiellonian University Bioethics Committee No. KBET/79/B/2014.

\section{Statistical Analysis}

A statistical analysis was carried out using the Microsoft Office Excel 2013 spreadsheet and Statgraphics Centurion software. Verification of the hypotheses about a relationship or lack thereof between particular features was carried out using the chi-square test of independence $\left(\chi^{2}\right)$ and Student's $t$-test for equivalence of means. A level of significance $\mathrm{p} \leq 0.05$ was accepted in all the conducted tests.

\section{RESULTS}

\section{Characteristics of Subjects}

The number of people taking part in the study was 252: 118 Seventh-day Adventists and 134 Catholics living in southern Poland. Comparing socio-demographic variables in two groups, it was observed that both Adventists and Catholics were most often town dwellers and represented most frequently by women. The average age was similar in both groups (SDA age 24-94 years vs C age 20-96 years). They were most frequently professionally active (employed), white collar workers, and their main source of income was their professional work. They differed in terms of education: SDA usually had secondary education, whereas Catholics - higher education. Adventists did not smoke cigarettes, whereas $17.20 \%$ of the Catholics did. Amongst these smokers there were 52\% women and 48\% men. Amongst these, the largest proportion, $17.40 \%$, have been smoking for over 20 years. Somewhat over half of the smokers $(52.20 \%)$ smoked 10 or fewer cigarettes per day, whilst nearly half (43.50\%): 11-20 cigarettes. 
The comparison of cardiovascular risk factors prevalence among Catholics and Seventh-day Adventists living in Southern Poland

Tab. 1. Results of biochemical tests in the study group of SDA and Catholics overall, according to age and gender

\begin{tabular}{|c|c|c|c|c|c|c|c|c|c|c|c|c|}
\hline \multirow{3}{*}{ Results } & \multicolumn{4}{|c|}{ Gender } & \multicolumn{6}{|c|}{ Age } & \multirow{2}{*}{\multicolumn{2}{|c|}{$\begin{array}{c}\text { Overall } \\
(\%)\end{array}$}} \\
\hline & \multicolumn{2}{|c|}{ Women (\%) } & \multicolumn{2}{|c|}{ Men (\%) } & \multirow{2}{*}{$\begin{array}{l}\text { SDA } \\
<39\end{array}$} & \multirow{2}{*}{$\begin{array}{c}C \\
<39\end{array}$} & \multirow{2}{*}{$\frac{\text { SDA }}{40-60}$} & \multirow{2}{*}{$\frac{C}{40-60}$} & \multirow{2}{*}{$\frac{S D A}{>60}$} & \multirow{2}{*}{$\frac{C}{>60}$} & & \\
\hline & SDA & $\mathrm{C}$ & SDA & C & & & & & & & SDA & C \\
\hline \multicolumn{13}{|c|}{ Total cholesterol } \\
\hline$\uparrow$ & 46.87 & 55.17 & 48.84 & 42.55 & 21.74 & 35.42 & 52.54 & 60.0 & 16.67 & 0.0 & 47.46 & 50.75 \\
\hline $\mathrm{p}$ & \multicolumn{2}{|c|}{$x^{2}=1.2 ; p=0.28$} & \multicolumn{2}{|c|}{$x^{2}=0.36 ; p=0.55$} & \multicolumn{2}{|c|}{$X^{2}=1.36 ; p=0.24$} & \multicolumn{2}{|c|}{$x^{2}=0.61 ; p=0.43$} & \multicolumn{2}{|c|}{$x^{2}=6.54 ; p=0.01^{*}$} & \multicolumn{2}{|c|}{$X^{2}=0.27 ; p=0.60$} \\
\hline \multicolumn{11}{|c|}{ mean concentration cholesterol in the group $(\mathrm{mg} / \mathrm{dl})$} & 201.55 & 205.02 \\
\hline \multicolumn{11}{|c|}{$\mathrm{p}$} & \multicolumn{2}{|c|}{$t=-0.65 ; p=0.52$} \\
\hline \multicolumn{13}{|c|}{ HDL cholesterol } \\
\hline$\uparrow$ & 17.33 & 10.34 & 0.00 & 0.00 & 0 & 6.25 & 11.88 & 12.00 & 16.67 & 0 & 11.02 & 6.72 \\
\hline$p$ & \multicolumn{2}{|c|}{$x^{2}=1.68 ; p=0.19$} & \multicolumn{2}{|c|}{ - } & \multicolumn{2}{|c|}{$x^{2}=1.50 ; p=0.22$} & $x^{2}=0$ & 0.98 & $x^{2}=6.5$ & $=0.01^{*}$ & $x^{2}=1.4$ & $=0.23$ \\
\hline mean con & ration HDL & olesterol & e group & & & & & & & & 57.13 & 51.96 \\
\hline$p$ & & & & & & & & & & & $\mathrm{t}=3.11$ & $=0.002^{*}$ \\
\hline & & & & & & choleste & & & & & & \\
\hline$\uparrow$ & 17.33 & 20.69 & 16.28 & 36.17 & 0 & 16.67 & 20.34 & 28.00 & 22.22 & 36.11 & 16.95 & 26.12 \\
\hline$p$ & $x^{2}=0.2$ & $=0.59$ & $x^{2}=4.5$ & $=0.03$ & $x^{2}=4.3$ & $=0.03^{*}$ & $x^{2}=0$. & $=0.34$ & $x^{2}=1$. & $=0.19$ & $x^{2}=3.09$ & $=0.08^{*}$ \\
\hline mean con & ration trig & rides in $t$ & roup (mg & & & & & & & & 103.53 & 129.29 \\
\hline$p$ & & & & & & & & & & & $\mathrm{t}=-2.72$ & $=0.007^{*}$ \\
\hline & & & & & & lucose (G & & & & & & \\
\hline$\uparrow$ & 10.67 & 8.05 & 10.30 & 14.89 & 4.35 & 4.17 & 8.47 & 10.00 & 19.44 & 19.44 & 11.02 & 10.45 \\
\hline$p$ & $X^{2}=0.7$ & $=0.40$ & $x^{2}=0.6$ & $=0.41$ & $x^{2}=0$. & $=0.97$ & $X^{2}=0$. & $=0.78$ & & & $X^{2}=0.0$ & $=0.88$ \\
\hline mean con & ration glu & in the $\mathrm{g}$ & $(\mathrm{mg} / \mathrm{dl})$ & & & & & & & & 101.67 & 99.09 \\
\hline$p$ & & & & & & & & & & & $\mathrm{t}=0.4$ & $=0.68$ \\
\hline & & & & & -reactive & ein conce & tion (CR & & & & & \\
\hline$\uparrow$ & 6.67 & 19.54 & 18.60 & 14.89 & 17.39 & 6.25 & 6.78 & 14.00 & 13.9 & 38.9 & 11.02 & 17.91 \\
\hline p & $x^{2}=5.6$ & $=0.02$ & $x^{2}=0.2$ & $=0.63$ & $x^{2}=2.1$ & $=0.14$ & $x^{2}=1$. & $=0.21$ & $x^{2}=5$ & $=0.02$ & $x^{2}=2.3$ & $=0.12$ \\
\hline mean con & ration CRP & the group & & & & & & & & & 3.16 & 3.66 \\
\hline$p$ & & & & & & & & & & & $\mathrm{t}=-0.5$ & $=0.55$ \\
\hline & & & & & & cysteine & & & & & & \\
\hline$\uparrow$ & 46.67 & 50.57 & 72.09 & 78.72 & 56.52 & 45.82 & 45.76 & 58.00 & 72.22 & 83.33 & 55.93 & 60.45 \\
\hline$p$ & $x^{2}=0.2$ & $=0.62$ & $x^{2}=0.5$ & $=0.64$ & $X^{2}=0.7$ & $=0.39$ & $x^{2}=1$. & $=0.20$ & $x^{2}=1$. & $=0.26$ & $x^{2}=0.5$ & $=0.47$ \\
\hline mean con & ration hon & ysteine ir & group $(\mu$ & & & & & & & & 13.69 & 16.01 \\
\hline$p$ & & & & & & & & & & & $\mathrm{t}=-2.0$ & $=0.04^{*}$ \\
\hline
\end{tabular}

Note. Chi-square test of independence $\left(x^{2}\right)$ and Student's t-test for equivalence of means above normal $=\uparrow ;{ }^{*} p \leq 0.05$

\section{Laboratory tests - lipid disorders, blood glucose disturbances, C-reactive protein, homocysteine}

Comparing the mean concentrations of biochemical parameters in the SDA group with those of Catholics, it turned out that the mean concentration of homocysteine, triglycerides, total cholesterol, and CRP was higher in Catholics. However, in Adventists, the mean concentration of HDL cholesterol and glucose was higher (Table 1).

\section{Physical examination}

Comparing the two groups, it can be stated that the percentage of Seventh-day Adventists with above normal blood pressure was significantly higher than that of Catholics. In the SDA group, the above normal blood pressure was observed significantly more frequently in both men and women, as well as in all the analysed age groups than in the Catholic group (Table 2).
- Tab. 2. Results of blood pressure measurements in the study group of SDA and Catholics overall, according to age and gender

\begin{tabular}{|c|c|c|c|c|c|c|}
\hline \multirow{2}{*}{\multicolumn{2}{|c|}{$\%$}} & Optimal & Normal & $\begin{array}{c}\text { High } \\
\text { normal }\end{array}$ & $\begin{array}{l}\text { Above } \\
\text { normal }\end{array}$ & \multirow{2}{*}{ p } \\
\hline & & $\%$ & $\%$ & $\%$ & & \\
\hline \multirow{2}{*}{ Women } & Catholics & 32.18 & 36.78 & 18.39 & 12.65 & \multirow{2}{*}{$\begin{array}{l}x^{2}=37.32 ; \\
p=0.000^{*}\end{array}$} \\
\hline & SDA & 41.33 & 6.67 & 10.67 & 41.33 & \\
\hline \multirow{2}{*}{ Men } & Catholics & 17.02 & 24.40 & 27.66 & 31.92 & \multirow{2}{*}{$\begin{array}{l}x^{2}=26.44 ; \\
p=0.0004^{*}\end{array}$} \\
\hline & SDA & 41.86 & 4.65 & 2.33 & 51.20 & \\
\hline \multirow{2}{*}{$\begin{array}{l}\text { Subjects up to } \\
39 \text { years of age }\end{array}$} & Catholics & 37.50 & 22.92 & 22.92 & 16.66 & \multirow{2}{*}{$\begin{array}{l}x^{2}=11.33 ; \\
p=0.04^{*}\end{array}$} \\
\hline & SDA & 60.87 & 8.70 & 0 & 30.43 & \\
\hline \multirow{2}{*}{$\begin{array}{l}\text { Subjects aged } \\
40-59 \text { years }\end{array}$} & Catholics & 24.16 & 34.00 & 20.00 & 22.00 & \multirow{2}{*}{$\begin{array}{l}x^{2}=28.36 ; \\
p=0.0002^{*}\end{array}$} \\
\hline & SDA & 47.46 & 5.08 & 5.08 & 42.38 & \\
\hline \multirow{2}{*}{$\begin{array}{l}\text { Subjects over } \\
60 \text { years }\end{array}$} & Catholics & 16.67 & 41.67 & 22.22 & 19.44 & \multirow{2}{*}{$\begin{array}{l}x^{2}=23.30 ; \\
p=0.002^{*}\end{array}$} \\
\hline & SDA & 19.44 & 5.56 & 16.67 & 58.33 & \\
\hline \multirow{2}{*}{ Overall } & Catholics & 26.87 & 32.09 & 21.64 & 19.41 & \multirow{2}{*}{$\begin{array}{l}x^{2}=55.39 ; \\
p=0.000^{*}\end{array}$} \\
\hline & SDA & 41.53 & 5.93 & 7.63 & 44.91 & \\
\hline
\end{tabular}

Note. chi-square test of independence $\left(X^{2}\right),{ }^{*} p \leq 0.05$ 


\section{Anthropometric measurements}

Comparing BMI in the two groups, a somewhat higher percentage of SDA was within the normal range. Among Catholics, almost twice as many individuals were obese, whilst the percentage of overweight subjects in both groups was the same. The differences between the results obtained for BMI in the two studied groups were not significant. When comparing android obesity, it was more common in Catholics than in SDA, but statistically insignificant (Table 3).

Tab. 3. Results BMI in the study group of SDA and Catholics overall, according to gender

\begin{tabular}{|c|c|c|c|c|c|c|}
\hline & \multirow[t]{2}{*}{$\%$} & $\begin{array}{l}\text { Under- } \\
\text { weight }\end{array}$ & Normal & $\begin{array}{c}\text { Over- } \\
\text { weight }\end{array}$ & Obesity & \multirow[t]{2}{*}{$p$} \\
\hline & & $\%$ & $\%$ & $\%$ & & \\
\hline \multirow{3}{*}{ Catholics } & Women, N- 87 & 3.45 & 47.13 & 31.03 & 18.39 & \multirow{6}{*}{$\begin{aligned} x^{2} & =8.75 ; \\
p & =0.12\end{aligned}$} \\
\hline & Men, N - 47 & - & 31.90 & 40.43 & 27.67 & \\
\hline & Overall, N - 134 & 2.24 & 41.79 & 34.33 & 21.64 & \\
\hline \multirow{3}{*}{ SDA } & Women, N - 75 & 1.33 & 56.01 & 32.00 & 10.66 & \\
\hline & Men, N - 43 & - & 44.18 & 39.54 & 16.28 & \\
\hline & Overall, $\mathrm{N}$ - 118 & 0.85 & 51.65 & 34.75 & 12.75 & \\
\hline
\end{tabular}

Note. chi-square test of independence $\left(x^{2}\right),{ }^{*} p \leq 0.05$

\section{Risk of cardiovascular events}

The Adventists most frequently had a moderate (44.90\%) or low (37.30\%) risk of cardiovascular events occurrence. However, high risk was diagnosed in $15.30 \%$ of the subjects, but very high only in $2.50 \%$ of the respondents. In contrast, the Catholics most frequently had a moderate $(52.20 \%)$ risk of cardiovascular events occurrence. Low risk was diagnosed in $20.90 \%$, high in $15.70 \%$, and very high in $11.20 \%$ of the respondents. The risk of cardiovascular events among Catholics was significantly higher than among Adventists, both, in the whole studied group $\left(\chi^{2}=13.17, p=0.04\right)$, and in individual age groups: up to 39 years of age $\left(\chi^{2}=10.48, \mathrm{p}=0.001\right), 40-59$ years $\left(\chi^{2}=17.43, p=0.0006\right)$, above 60 years $\left(\chi^{2}=13.9\right.$, $\mathrm{p}=0.001)$, and in men $\left(\chi^{2}=20.08, \mathrm{p}=0.0002\right)$. Amongst women, it was insignificant $\left(\chi^{2}=6.77, \mathrm{p}=0.08\right)$.

\section{DISCUSSION}

A review literature concerning the religious affiliation and that of cardiovascular disease did not show any clear correlations between these variables [12-14]. Some studies, especially among Adventists, showed the influence of taking up religious practices on a reduction in mortality [15-18]. However, there are also some studies showing lack of such correlation $[19,20]$.

In recent years there has been no report in the Polish literature on the prevalence of cardiovascular risk factors among SDA and Catholics. The authors of the present study decided to compare their own results with those of the nationwide Polish research: NATPOL PLUS 2002 and WOBASZ 2003-2005. For example, an elevated level of homocysteine was diagnosed among SDA (55.93\%) and Catholics $(60.45 \%)$. It was a result of over twice, and in Catholics even three times higher than in the overall Polish population (17\%) in the NATPOL PLUS study [21].
Overweight (34.33\%) and obesity (21.64\%) in the case of Catholics were more similar to the nationwide population (33.6\%, 19.1\% respectively) in the NATPOL PLUS study [21]. Android obesity defined on the basis of waist circumference was lower among SDA (27.12\%: W 33.33\%, M 16.28\%) in relation to Catholics (36.57\%: W 40.23\%, M 29.79\%) and the overall Polish population (W 35\%, M 19\%) in the NATPOL PLUS study [21]. As far as hypertensive individuals are concerned, their proportion was decidedly higher, among SDA (44.91\%), and amongst Catholics (19.41\%) decidedly lower than in the overall Polish population, both in the NATPOL PLUS (29\%) and in WOBASZ (36\%) [21-24]. Considering hypercholesterolemia, a higher percentage of persons with hypercholesterolemia was noted among Catholics (51\%) than among SDA (48\%), which anyway was a lower percentage compared to the overall Polish population both in the NATPOL PLUS study (W 62\%, M 60\%) and WOBASZ (W 64\%, M 67\%) [21-24]. These differences can be accounted for by many factors, including regional specificity, psychosocial and economic variables, the respondents' lifestyle and religious affiliation. For example, people living in less affluent areas, among other areas of Southern Poland, may be exposed to higher risk of cardiovascular disease.

The study carried out in southern Poland shows clearly that the risk was significantly higher in Catholics, especially in men. This can be accounted for by the fact that the Adventist group was characterized by some important factors essential in protection against cardiovascular disease: in spite of having significantly higher blood pressure values (which was surprising), their mean concentration of 'good cholesterol' (HDL) was significantly higher than in the Catholics, there was a lower percentage of android obesity, and they did not smoke. Similarly, in large clinical trials a stronger correlation (stronger predictive value) was ascertained between an indicator of abdominal obesity than of general obesity and myocardial infarction both in men and women [25].

It seems that the research conducted among Polish ADS and Catholics is important and interesting. Cardiovascular diseases develop slowly. Symptoms often appear only in advanced stages of the disease. The role of health care workers is to detect these diseases at an early stage not only in the general population, but also among religious groups. It is also important to counteract them by eliminating or modifying risk factors within primary and secondary prevention. These actions may lead to a reduction in mortality, improving survival, limiting the need for interventional procedures, and improving the quality of life in these groups. These studies focus not only on the occurrence of "classical" risk factors (total cholesterol, HDL cholesterol, triglycerides, glucose), but also "new" (C-reactive protein concentration - CRP, homocysteine). The significance of the aforementioned factors in the pathogenesis of cardiovascular events and the development of atherosclerosis have been studied in the last decade in the general population but not among religious groups. These studies also show the risk of cardiovascular events occurrence in the next 10 years among ADS and Catholics. 
The results of the study presented in the article may rise awareness - among nurses, clinicians and public health professionals working in the field of cardiovascular disease prevention - on the subject of cardiovascular disease risk among SDA and Catholics in Poland. This result has been provided by the research conducted by Fernandez et al. among Asian Indians living in Australia [26], which raised awareness on the subject of coronary heart disease risk, or research by Anthony et al. [27] on the lifestyles of ethnic groups. However, further research will be necessary, which should focus on diseases of the cardiovascular system among Catholics and SDA as well as other religious or ethnic groups. This can also be a good study to compare to other regions with similar Catholic and SDA populations and culture.

\section{CONCLUSIONS}

The study showed high prevalence of "classical" and "new" CVD risk factors among SDA and Catholics living in southern Poland. The study demonstrated greater prevalence of CVD risk factors and significantly higher risk of cardiovascular events among Catholics. The results of the study indicate important action points in CVD prevention, the need to develop integrated educational interventions and screening involving nurses, doctors, and public health professionals to be conducted, especially among Catholics. Nurses, especially environmental ones, should modify and intensify preventive actions among Catholics. These activities should increase motivation for lifestyle changes (e.g. to fight obesity), regular blood pressure and body mass measurements and control of blood biochemical parameters, such as homocysteine, cholesterol.

\section{REFERENCES}

1. Jędrychowski W, Tobiasz-Adamczyk B, Olma A, Gradziliewicz P. Survival Rates Among Seventh-day Adventists Compared with the general population of Poland. Scand J Social Medic. 1985; 13(2): 49-52.

2. Pawlikowski J, Marczewski K. (2008). Religia a zdrowie - czy religia może sprzyjać trosce 0 zdrowie? Cześć 1 - wartość zdrowia w wielkich religiach świata. Kardiol Dypl. 2008; 7(10): 96-103.

3. Pawlikowski J, Sak J, Marczewski K. Religia a zdrowie - czy religia może sprzyjać trosce o zdrowie?. Część 2 - religijność a zdrowie. Kardiol Dypl. 2009; 8(1): 87-94.

4. Majda A, Zalewska-Puchała J, Bodys-Cupak I, i wsp. Rozpowszechnienie czynników ryzyka chorób sercowo-naczyniowych wśród wyznawców Kościoła Adwentystów Dnia Siódmego zamieszkujących teren Polski Południowej. Probl Piel. 2015; 23(2): 190-196. doi: 10.5603/PP.2015.0032

5. Modrzejewski W, Musiał WJ. Stare i nowe czynniki ryzyka sercowo-naczyniowego - jak zahamować epidemię miażdżycy? Część I. Klasyczne czynniki ryzyka. Forum Zaburzeń Metabol. 2010; 2(1): 106-114.

6. Matetzky S, Freimark D, Ben-Ami S, et. al. Association of elevated homocysteine levels with a higher risk of recurrent coronary events and mortality in patients with acute myocardial infarction. Archiv Inter Medic. 2003; 163(16): 1933-1937. doi:10.1001/archinte.163.16.1933

7. Yusuf $S$, Hawken $S$, Ounpuu $S$, et. al. Effect of potentially modifiable risk factors associated with myocardial infarction in 52 countries (the INTERHEART study): casecontrol study. Lancet, 2004; 364: 937-952. doi:10.1016/S0140-6736(04)17018-9
8. Broda G, Rywik S. Wieloośrodkowe ogólnopolskie badanie stanu zdrowia ludności - projekt WOBASZ. Zdefiniowanie problemu oraz cele badania. Kardiol Pol. 2005; 63: 6 (Suppl. 4): 601-604.

9. European guidelines on cardiovascular disease prevention in clinical practice, version 2012. Europejskie Wytyczne dotyczące zapobiegania chorobom serca i naczyń w praktyce klinicznej na 2012 rok. Kardiol Pol. 2012; (Suppl. I): S1-S100.

10. Cybulska B, Szostak WB, Kłosiewicz-Latoszek L. Zapobieganie chorobom układu krążenia. [w:] P. Gajewski P, red. Interna Szczeklika. Podręcznik chorób wewnętrznych. Kraków: Medycyna Praktyczna; 2014, s. 149-159.

11. Majda A, Zalewska-Puchała J, Kamińska A, et. al. Risk factors for diseases of the cardiovascular system among Catholics living in areas of Southern Poland. Stud Med. 2017; 33(2): 88-94. doi: 10:5114/ms.2017.68701

12. Lucchese FA, Koenig HG. Religion, spirituality and cardiovascular disease: research, clinical implications, and opportunities in Brazil. Revista Brasileira Cirurgia Cardiovascular, 2013; 28(1): 103-28. http://dx.doi.org/10.5935/1678-9741.20130015

13. Salmoirago-Blotcher $E$, Fitchett $G$, Hovey KM, et. al. Frequency of private spiritual activity and cardiovascular risk in postmenopausal women: the Womenn's Health Initiative. Annals Epidemiol. 2013; 23(5): 239-245. doi: 10.1016/j. annepidem.2013.03.002.

14. Valenti VE, Quitério RJ, Barnabe V, et al. Spirituality/religiosity and cardiovascular system. OA Alternative Medicine, 2014; 2(1): 1-5.

15. Appel L.J, Miller E.R, Ha JeeS, et al. Effect of dietary patterns on serum homocysteine. Results of a randomized, controlled feeding study. Circulation, 2000; 102(8): 852857.

16. Heuch I, Jacobsen BK, Fraser GE. A cohort study found that earlier and longer Seventh-day Adventist church membership was associated with reduced male mortality. J Clinical Epidemiol. 2005; 58(1): 83-91.

17. KwokCS, Umar S, Myint PK, et. al. Vegetarian diet, Seventh Day Adventists and risk of cardiovascular mortality: a systematic review and meta-analysis. Int J Cardiol. 2014; 176(3): 680-686. doi: 10.1016/j.jicard.2014.07.080

18. Orlich MJ, Singh PN, Sabate J, et. al. Vegetarian Dietary Patterns and Mortality in Adventist Health Study 2. JAMA Internal Medic. 2013; 173(13): 1230-1238. doi: 10.1001/jamainternmed.2013.6473

19. Bell CN, Bowie JV, Thorpe RJ. The interrelationship between hypertension and blood pressure, attendance at religious services, and race/ethnicity. J Relig Health, 2012; 51(2): 310-322, doi:10.1007/s10943-010-9346-7

20. Feinstein $M$, Liu K, Ning $H$, et. al. Burden of cardiovascular risk factors, subclinical atherosclerosis, and incident cardiovascular events across dimensions of religiosity: The multi-ethnic study of atherosclerosis. Circulation, 2010; 121(5): 659-66. doi: $10.5402 / 2012 / 278730$

21. Zdrojewski T, Bandosz P, Szpakowski P, i wsp. Rozpowszechnienie głównych czynników ryzyka chorób układu sercowo-naczyniowego w Polsce. Wyniki badania NATPOL PLUS. Kardiol Pol. 2004; 61, 5-26.

22. Biela U, Pająk A, Kaczmarczyk-Chałas K, i wsp. (2005). Częstość występowania nadwagi i otyłości u kobiet i mężczyzn w wieku 20-74 lat. Wyniki programu WOBASZ. Kardiol Pol. 2005; 63, 6 (Suppl. 4): 632-635.

23. Sygnowska E, Waśkiewicz A. Sposób żywienia osób z hipercholesterolemią stosujących odpowiednią dietę i niestosujących diety. Bromatol Chem Toksykol. 2012; XLV 3: 608-613.

24. Zdrojewski T. Występowanie i świadomość nadciśnienia tętniczego w Polsce i na świecie. Postępy Nauk Med. 2011; 3: 4-10.

25. Yusuf $S$, Hawken $S$, Ounpuu $S$, et. al. Obesity and the risk of myocardial infarction in 27,000 participants from 52 countries: a case-control study. Lancet, 2005; 366: 1640-1649. doi: 10.1016/S0140-6736(05)67663-5

26. Fernandez R, Rolley JX, Rajaratnam R, et. al. Risk factors for Coronary Heart Disease among Asian Indians living in Australia. J Transcult Nurs. 2015; 26(1): 57-63. doi: 10.1177/1043659614523996

27. Anthony D, Baggott R, Tanner J, et. al. Health, lifestyle, belief and knowledge differences between two ethnic groups with specific reference to tobacco, diet and physical activity. J Adv Nurs. 2012; 68(11): 2496-2503, doi: 10.1111/j.1365-2648.2012. 05948-x

Manuscript received: 20.09.2017

Manuscript accepted: 03.10.2017 